\title{
Logical Memory II Subtest (WMS-IV)
}

National Cancer Institute

\section{Source}

National Cancer Institute. Logical Memory II Subtest (WMS-IV). NCI Thesaurus. Code C120343.

A subtest of the Wechsler Memory Scale, 4th Edition that assesses narrative memory under a free recall condition. A short story is presented orally. After a delay, the subject is asked to recall the story from memory. 